\title{
KARAKTER TOKOH UTAMA DALAM NOVEL SURGA YANG TAK DIRINDUKAN SERTA APLIKASINYA DALAM PEMBELAJARAN BAHASA DAN SASTRA INDONESIA
}

\author{
Rerin Maulinda \\ Sastra Indonesia, Universitas Pamulung, rerin 30@yahoo.co.id
}

\begin{tabular}{l} 
INFO ARTIKEL \\
\hline Riwayat Artikel: \\
Diterima: 03-09-2017 \\
Disetujui: 30 -09-2017
\end{tabular}

Kata Kunci:

Karakter

Tokoh

Novel dan Sastra

\begin{abstract}
ABSTRAK
Abstrak - Dalam pandangan umum sebuah nilai terwadahi dalam kerangka kebudayaan masyarakat, karena kebudayaan merupakan salah satu sistem nilai. Di tataran filsafat dan kebudayaan, Sutan Takdir Alisyahbana dan Ki Hajar Dewantara mengenalkan rasa kebangsaan itu melalui proses kristalisasi konsep budaya bangsa. Dalam pengembangan budaya bangsa harus berlandaskan pada nilai-nilai sosial bangsa yang selama ini telah berperan besar dalam memajukan bangsa Indonesia. Karya sastra menjadi sarana untuk menyampaikan pesan tentang kebenaran, tentang apa yang baik dan yang buruk. Karya sastra seharusnya memberi manfaat positif bagi pembaca. Kandungan nilai yang tersimpan dalam karya sastra harus digali agar sampai kepada pembaca. Karya-karya sastra yang memberikan nilai-nilai sebagaimana fungsi sastra utile memberikan kegunaan kepada pembaca. Penerapan nilai-nilai tersebut akan berkontribusi pada pembentukan karakter individu maupun masyarakat yang akan mampu meretas nilai-nilai inti yang luhur sehingga dapat digunakan sebagai pilot pembentukan budaya bangsa secara nasional. Dalam hal ini, karya sastra sangat mendukung pembentukan karakter sesorang yang disebabkan oleh alur kisahnya. Karakter Tokoh Utama yang terdapat dalam novel Surga Yang Tak Dirindukan, berdasarkan hasil analisis terdiri dari enam karakter tokoh utama. Adapaun karakter tokoh utamadalam novel Surga Yang Tak Dirindukan, yaitu: (a) Religius. (b) Peduli Lingkungan. (c)Kreatif. (d) Toleransi. (e) Tanggung Jawab. (f) Kerja Keras.
\end{abstract}

\begin{abstract}
In general view a value is embodied within the framework of the culture of society, because culture is one of the value system. At the level of philosophy and culture, Sutan Takdir Alisyahbana and Ki Hajar Dewantara introduce the sense of nationality through the process of crystallizing the nation's cultural concept. In the development of the nation's culture must be based on the social values of the nation that has been playing a major role in advancing the nation of Indonesia. Literary works are a means to convey the message of truth, about what is good and what is bad. Literary works should have positive benefits for the reader. The content of the value stored in the literary works must be extracted to reach the reader. Literary works that provide values as well as utility literary functions provide usefulness to the reader. Implementation of these values will contribute to the formation of individual characters and communities that will be able to pave the core values of the noble so that it can be used as a pilot of national culture formation nationally. In this case, literary works strongly support the formation of one's character caused by the plot of the story. The character of the main character in the novel of the Unwanted Heaven, based on the analysis result consists of six characters of the main character. The characters of the main characters in the novel of Heaven Not Missed, namely: (a) Religious. (b) Care for the Environment. (c) Creative. (d) Tolerance. (e) Responsibility. (f) Hard Work.
\end{abstract}

\section{A. LATAR BELAKANG}

Bangsa yang maju tidak semata-mata disebabkan oleh kompetensi, teknologi canggih, atau kekayaan alamnya, tetapi yang terutama adalah dorongan semangat dan karakternya. Di Indonesia akhir-akhir ini dijumpai fenomena sosial, antara lain penyimpangan yang dilakukan pelajar seperti seks bebas, tawuran, maupun ditemukannya beberapa video tak sepantasya. Kondisi ini menimbulkan kecurigaan masyarakat mengenai kegagalan pendidikan. Pendidikan selama ini lebih cenderung memberikan porsi yang berlebih pada penanaman aspekaspek kompetensi hard skills dan kurang memberi porsi yang layak pada penanaman soft skills.

Salah satu untuk meminimalkan berbagai masalah di atas adalah dengan membenahi karakter anak bangsa. Jika masyarakat memiliki karakter yang kuat, maka berbagai tindakan amoral dapat dihindari. Hal ini dapat dilakukan dengan memasukkan pendidikan karakter di dalam 
keluarga, masyarakat dan di sekolah pada khususnya. Salah satu cara untuk membentuk siswa berkarakter di lingkungan sekolah yakni melalui pembelajaran bahasa dan sastra Indonesia.

Sastra sebagai karya seni tercipta karena adanya energi imajinatif dan luapan perasaan pengarang yang disampaikan secara lisan dan tulisan ke tengah-tengah masyarakat. Sebagai karya seni, karya sastra memiliki peranan penting dalam kehidupan manusia. Efek penyumbangsihan pengarang pada kehidupan, nilai-nilai estetika dan etika serta kehidupan yang lengkap ini tidak begitu segera dapat dirasakan. Ia membutuhkan proses dan reproses serta perjalanan waktu (Suyitno, 1986: 9).

Dalam pandangan umum sebuah nilai terwadahi dalam kerangka kebudayaan masyarakat, karena kebudayaan merupakan salah satu sistem nilai. Di tataran filsafat dan kebudayaan, Sutan Takdir Alisyahbana dan Ki Hajar Dewantara mengenalkan rasa kebangsaan itu melalui proses kristalisasi konsep budaya bangsa. Dalam pengembangan budaya bangsa harus berlandaskan pada nilai-nilai sosial bangsa yang selama ini telah berperan besar dalam memajukan bangsa Indonesia.

Karya sastra menjadi sarana untuk menyampaikan pesan tentang kebenaran, tentang apa yang baik dan yang buruk. Karya sastra seharusnya memberi manfaat positif bagi pembaca. Kandungan nilai yang tersimpan dalam karya sastra harus digali agar sampai kepada pembaca. Karya-karya sastra yang memberikan nilai-nilai sebagaimana fungsi sastra utile memberikan kegunaan kepada pembaca.

Penerapan nilai-nilai tersebut akan berkontribusi pada pembentukan karakter individu maupun masyarakat yang akan mampu meretas nilai-nilai inti yang luhur sehingga dapat digunakan sebagai pilot pembentukan budaya bangsa secara nasional. Dalam hal ini, karya sastra sangat mendukung pembentukan karakter sesorang yang disebabkan oleh alur kisahnya.

Karya sastra di samping menunjukan sifatnya yang rekreatif, ia juga merupakan dian penerang yang mampu membawa manusia mencari nilai-nilai yang dapat menolongnya untuk menemui hakikat kemanusiaan yang berkepribadian.

Karya sastra merepresentasikan nilai-nilai budaya dan sosial kelompok orang tertentu, bukan kebenaran universal dari sifat dasar manusia, dan hanya merupakan salah satu bentuk ekspresi material dari pengalaman manusia.

Dalam pengembangan budaya dan karakter bangsa sebagaimana yang disampaikan oleh Dodi Nandika pada pembukaan Seminar Antarbangsa Kesusasteraan Asia Tenggara mengatakan, kemajuan bangsa tergantung kemampuan bangsa dalam mendayagunakan potensi dan karakter. Bagi bangsa yang cerdas, bahasa dan sastra adalah sumberdaya strategis untuk mengembangkan kreasi, inovasi, dan keunggulan peradaban bangsa. Karakter bangsa harus diperkuat antara lain dengan bahasa dan sastra sebagai pilar penting (Sugiarti, 2011).

Membaca karya sastra secara intensif pada hakikatnya secara tidak sadar merekonstruksi sikap dan kepribadian pembaca. Karya sastra selain sebagai penanaman nilainilai karakter juga akan merangsang imajinasi pembaca dalam berpikir kritis melalui rasa ingin tahu terhadap jalan cerita.
Fungsi dan tujuan pendidikan nasional, yaitu "Pendidikan nasional berfungsi mengembangkan dan membentuk watak serta peradaban bangsa yang bermartabat dalam rangka mencerdaskan kehidupan bangsa, bertujuan untuk berkembangnya potensi peserta didik agar menjadi manusia yang beriman dan bertakwa kepada Tuhan Yang Maha Esa, berakhlak mulia, sehat, berilmu, cakap, kreatif, mandiri, dan menjadi warga negara yang demokratis serta bertanggung jawab" (Sumber: Undang-undang Republik Indonesia Nomor 20 Tahun 2003 tentang Sistem Pendidikan Nasional).

Pendidikan karakter bukan hanya sekedar mengajarkan mana yang benar dan mana yang salah. Lebih dari itu, pendidikan karakter adalah usaha menanamkan kebiasaan-kebiasaan yang baik sehingga peserta didik mampu bersikap dan bertindak berdasarkan nilai-nilai yang telah menjadi kepribadiannya. Dengan kata lain, pendidikan karakter yang baik harus melibatkan pengetahuan yang baik (moral knowing), perasaan yang baik atau loving good (moral feeling) dan perilaku yang baik (moral action) sehingga terbentuk perwujudan kesatuan perilaku dan sikap hidup peserta didik.

Pendidikan karakter bertujuan mengembangkan nilainilai yang membentuk karakter bangsa yaitu Pancasila, meliputi : (1) mengembang-kan potensi peserta didik agar menjadi manusia berhati baik, berpikiran baik, dan berperilaku baik; (2) membangun bangsa yang berkarakter Pancasila; (3) mengembangkan potensi warga negara agar memiliki sikap percaya diri, bangga pada bangsa dan negaranya serta mencintai umat manusia.

Pendidikan karakter berfungsi (1) membangun kehidupan kebangsaan yang multikultural; (2) membangun peradaban bangsa yang cerdas, berbudaya luhur, dan mampu berkontribusi terhadap pengembangan kehidupan umat manusia; mengembangkan potensi dasar agar berhati baik, berpikiran baik, dan berperilaku baik serta keteladanan baik; (3) membangun sikap warga negara yang cinta damai, kreatif, mandiri, dan mampu hidup berdampingan dengan bangsa lain dalam suatu harmoni.

Pendidikan karakter dilakukan melalui berbagai media yaitu keluarga, satuan pendidikan, masyarakat, pemerintah, dunia usaha, dan media massa. Pendidikan karakter telah menjadi perhatian berbagai negara dalam rangka mempersiapkan generasi yang berkualitas, bukan hanya untuk kepentingan individu warga negara, tetapi juga untuk warga masyarakat secara keseluruhan.

Pendidikan karakter dapat diartikan sebagai the deliberate us of all dimensions of school life to foster optimal character development (usaha kita secara sengaja dari seluruh dimensi kehidupan sekolah/ madrasah untuk membantu pembentukan karakter secara optimal. Pembentukan karakter pada peserta didik dapat dilakukan dengan media sastra salah satunya novel. Dalam uraian ini, penulis akan membahas macam-macam nilai karakter yang dimiliki tokoh utama pada novel Surga yang tak Dirindukan karya Asma Nadia.

\section{B. METODE PENELITIAN}

Penelitian dilakukan pendekatan secara kualitatif. Karena data-data yang dikumpulkan berdasarkan catatan langsung, catatan resmi, catatan lapangan dan lain sebagainya. Sehingga tujuannya menggambarkan secara jelas proses pembelajaran dengan teori yang diangkat. 
Jenis penelitian ini adalah penelitian deskriptif. Penelitian deskriptif menguraikan proses pembelajaran.

\section{HASIL DAN PEMBAHASAN}

Adapun metode yang digunakan dalam menganalisa novel Surga yang Tak Dirindukan adalah:

\section{Metode Pembelajaran}

Adapun metode yang digunakan dalam menganalisa novel Surga yang Tak Dirindukan adalah:

\section{a. Metode diskusi}

Menurut leal (1990), diskusi memiliki penekanan khusus dalam proses pembelajaran ini karena, "akuisisi pengetahuan oleh peserta didik tidak terbatas pada konstruksi makna yang sifatnya pribadi, melainkan makna itu terentuk dan terbentuk kembali melalui prosese social yang panjang. Selain itu, tidaklah mungkin bagi kita memiliki interpretasi yang relative sahih dan objektif terlepas dari konteks social sebuah komunitas.

\section{b. Metode riset atau penelitian}

Dalam pembelajaran sastra, siswa perlu diajak untuk mendalami dengan lebih jauh persoalan moral yang ada didalam teks, sehingga siswa dapat memahami secara lebih mendalam persoalan-persoalan moral yang terdapat didalam teks. Ini akan dapat membuat para siswa semakin terbuka pemahaman dan wawasannya.

\section{Karakter Tokoh Utama}

Tokoh utama dalam novel Surga yang tak Dirindukan karya Asma Nadia bernama Arini. Arini adalah seorang ibu rumah tangga yang sholihah dan memiliki tiga orang anak. Novel tersenut menceritakan kehidupan rumah tangga Arini yang semula indah menjadi penuh air mata. Kesedihan Arini timbul karena ada wanita yang mengaku sebagai Nyonya Pras kedua. Hal tersebut membuat Arini tahu bahwa suaminya telah menikah lagi. Dalam novel tersebut Arini banyak memiliki nilai-nilai karakter positif yang dapat diimplikasikan dalam pembelajaran.

Adapun Nilai-nilai karakter dari tokoh Arini yang terdapat dalam novel Surga Yang Tak Dirindukan:

\section{a. Religius}

Religius dapat diartikan bersifat keagamaan. Latar belakang tokoh Arini berasal dari agama Islam. Karakter religius diwujudkan dengan taat beribadah, selalu bersyukur kepada Allah, menjalankan semua perintah Allah dan menjauhi semua larangan Allah. Nilai karakter religius pada novel Surga yang tak Dirindukan karya Asma Nadia dapat dilihat dari kutipan berikut ini.

\section{Kutipan 1}

Dan bagi Arini kalimat itu berarti: Sabar untuk tidak pacaran. Sabar menanti lelaki yang mendekatinya dengan niat menikah dan bukan sekedar meraih kehangatan masa muda. (Surga yang tak Dirindukan, 2014: 8).

Kutipan di atas menggambarkan Arini yang dengan sabar menaati perintah agama untuk tidak berpacaran seperti kebanyakan remaja. Dalam kutipan tersebut, Arini sabar untuk menanti lelaki yang mendekatinya dengan niat menikah dan bukan hanya meraih kehangatan masa muda saja. Arini adalah orang yang sangat menaati perintah agama dalam hubungan antara lelaki dan perempuan. Dalam agama Islam tidak mengenal budaya pacaran dan Arini sangat mematuhi hal itu. Jadi, kutipan di atas menunjukkan karakter Arini yang religius.

\section{Kutipan 2}

Arini percaya takdir. Dengan keyakinan itu dia telah melewati ribuan hari. Kadang memang keingintahuannya menggelitik. Pangeran mana yang akan Allah kirimkan padanya, bila memang kesempatan itu ada sebelum dia menjadi tawanan kematian? (Surga yang tak Dirindukan, 2014: 9).

Karakter religius dalam tokoh Arini juga dapat dilihat dari kutipan 2 yang menceritakan Arini percaya kepada takdir Allah. Arini yakin bahwa Allah akan mengirimkan pasangan hidup untuknya tanpa harus pacaran terlebih dahulu. Hal tersebut Arini lakukan semata-mata untuk menjadi muslimah yang bertaqwa. Arini ingin menjadi orang yang melakukan perintah Allah dan menjauhi larangan-larangan Allah.

\section{Kutipan 3}

Arini menggeleng. Si sulung kontan menghentikan aksi teror bantal ke adiknya. "Kalian sholat sama-sama, lalu kita makan, ya?" (Surga yang tak Dirindukan, 2014: 13).

Kutipan 3 menunjukkan Arini mendidik anaknya sesuai dengan agama Islam. Kutipan tersebut menceritakan tentang Arini yang memerintahkan anak-anaknya agar sholat samasama atau berjamaah. Hal tersebut menunjukkan sebagai seorang ibu Arini mendidik anaknya untuk menjadi anak yang sholeh dan sholihah. Arini menanamkan pilar-pilar agama Islam pada anakanaknya. Jadi, kutipan di atas menggambarkan karakter Arini yang religius.

\section{Kutipan 4}

Dia dan Pras melakukan sholat sunah berdua sehabis pernikahan sederhana itu. (Surga yang tak Dirindukan, 2014: 29).

Karakter religius yang dimiliki Arini juga dilukiskan pada kutipan di atas. Kutipan tersebut menceritakan bahwa Arini orang yang melakukan ibadah-ibadah yang dianjurkan agama Islam. Arini tidak hanya melakukan sholat wajib lima waktu tapi ia juga melakukan sholat sunah. Hal ini membuktikan Arini memiliki karakter religius karena taat dengan perintah Allah.

\section{Kutipan 5}

Allah, jangan biarkan iman yang sedikit ini terampas waktu. (Surga yang tak Dirindukan, 2014: 91).

Kutipan di atas merupakan doa yang diungkapkan Arini ketika ia melihat perubahan Lia yang sangat mengejutkan. Lia yang tadinya 
perempuan sholihah kini tidak memakai jilbab lagi dan malah merokok. Hal itu dilakukan Lia setelah bercerai dengan suaminya Benny karena Benny berselingkuh. Arini menyadari Lia kecewa dengan kehidupannya tapi Arini masih tidak percaya dengan hal yang dilihatnya itu. Arini mengucapkan doa pada kutipan di atas. Arini ingin keimanannya tetap terjaga meski waktu terus berjalan. Doa Arini di atas menunjukkan Arini memiliki karakter religius karena ingin selalu beriman kepada Allah.

\section{Kutipan 6}

Setelah semua bakti itu, Arini merasa telah berusaha semaksimal mungkin untuk menjadi istri yang sholihah. Dulu dikiranya itu cukup. (Surga yang tak Dirindukan, 2014: 110).

Sebagai istri yang baik, Arini selalu berusaha maksimal untuk melakukan kewajibankewajibannya. Arini telah menjadi istri yang baik bagi suaminya dan anak-anaknya. Arini berusaha menjadi istri yang sholihah. Usaha Arini untuk memenuhi kewajibannya sebagai seorang istri yang sholihah. Jadi kutipan 6 menunjukkan Arini memiliki karakter religius.

\section{Kutipan 7}

Seperti bunga rumput yang diempaskan angin pada musim kemarau. Begitulah hati Arini. Allah... desah Arini dengan lidah yang terasa kelu. (Surga yang tak Dirindukan, 2014: 226).

Kutipan di atas menceritakan hati Arini setelah melihat Pras bersama dengan istri keduanya. Arini merasa sangat sedih dan tidak berdaya. Ia mengumpamakan dirinya bagai bunga rumput yang diempaskan angin pada musim kemarau. Hal itu berarti Arini sangat merasa kecewa dengan Pras. Namun Arini tetap mengingat nama Allah walaupun dalam keadaannya yang sangat sedih dan kecewa. Dalam keadaannya yang tak berdaya, Arini masih bisa menyebut nama Allah meski lidahnya terasa kelu karena masalah besar yang ia hadapi. Hal tersebut membuktikan bahwa Arini memiliki karakter religius.

\section{Kutipan 8}

Beberapa saat ibu dan anak hanya bertatapan sampai Arini terhenyak bangkit dari tempat duduk dan berlari ke belakang rumah. Memandang anakanaknya lekat, dengan mata berkaca yang dirambati syukur. (Surga yang tak Dirindukan, 2014: 256).

Kutipan di atas menggambarkan Arini yang bersyukur karena memiliki anak-anak yang sangat ia sayangi. Rasa syukur merupakan wujud terima kasih kepada Allah atas semua hal yang telah diberikan Allah. Arini bersyukur sampai matanya berkaca-kaca karena menyadari karunia Allah begitu indah. Hal tersebut menunjukkan bahwa Arini memiliki karakter religius.

\section{Kutipan 9}

Arininya sholihah. Sholat malamnya rajin. Puasa Senin-Kamis pun rutin. Hari-harinya hanya terisi kesibukan menulis di rumah dan sesekali mengisi seminar. Bahkan hendak pergi ke pasar, atau mengajak anak-anak ke rumah saudara, perempuan itu selalu meminta izinnya. (Surga yang tak Dirindukan, 2014: 269)

Kutipan di atas Arini seorang wanita sholihah yang rajin sholat malam dan puasa Senin-Kamis. Sebagai seorang istri, Arini selalu meminta izin kepada suaminya saat ia ingin keluar rumah. Hal tersebut membuktikan Arini menjalankan kewajibannya sebagai istri sesuai dengan hukum agama Islam. Jadi kutipan di atas menunjukkan Arini memiliki karakter religius.

\section{b. Peduli Lingkungan}

Peduli terhadap lingkungan merupakan saah satu nilai-nilai karakter yang memiliki relevansi terhadap pembelajaran. Peduli lingkungan dapat diwujudkan dengan menjaga kelestarian dan kebersihan lingkungan di sekitar kita. Peduli lingkungan diperlukan untuk hidup sehat dan terhindar dari berbagai bencana. Berikut ini kutipan yang menunjukkan karakter peduli lingkungan dalam novel Surga yang tak Dirindukan karya Asma Nadia.

Arini terpaku di tempatnya. Pelan, matanya menelusuri kamar yang didominasi warna putih. Tempat tidur, lampu meja, lemari dan gorden di kamar itu yang senada itu dulu tampak sempurna di matanya. Dengan tangannya pula ia selalu menjaga kebersihan dan kerapian kamar, meski tiga anaknya tak jarang memberi pekerjaan ekstra karena kesukaan mereka mengekspansi tiap sudut rumah. (Surga yang tak Dirindukan, 2014: 3).

Kutipan di atas menunjukkan Arini peduli terhadap lingkungan tempat tinggalnya. Arini selalu menjaga kebersihan dan kerapian kamarnya. Sebagai ibu rumah tangga, Arini sangat rajin karena menata dan membersihkan kamarnya dengan tangannya sendiri. Hal yang dilakukan Arini tersebut menunjukkan Arini memiliki karakter peduli lingkungan.

\section{c. Kreatif}

Kreatif dapat berarti memiliki daya cipta atau memiliki kemampuan untuk menciptakan sesuatu. Orang yang kreatif akan melahirkan karya-karya yang berguna bagi orang lain. Karakter ini sangat dibutuhkan untuk mewujudkan peserta didik yang produktif. Dalam novel Surga yang tak Dirindukan karya Asma Nadia, karakter kreatif dapat dilihat dalam kutipan berikut.

Melewati tahun-tahun pernikahan, dia tak pernah menyesali satu hari pun. Istrinya cantik, berprestasi pula. Akhir-akhir ini makin sering Arini menerima undangan untuk bicara dalam forumforum kepenulisan. Beberapa peghargaan tingkat 
nasional pun sering diraih. (Surga yang tak Dirindukan, 2014: 37).

Kutipan di atas menceritakan bahwa Arini adalah seorang penulis. Pras menceritakan karir Arini sebagai penulis dalam kutipan di atas. Arini berprestasi di dunia kepenulisan. Arini juga menerima beberapa penghargaan tingkat nasional untuk karya-karyanya. Karya-karya Arini ini membuktikan bahwa Arini orang yang kreatif. Arini orang yang mampu menghasilkan suatu karya bahkan sampai mendapatkan penghargaan di tingkat nasional. Dari kutipan di atas, dapat disimpulkan bahwa Arini memiliki karakter kreatif.

\section{d. Toleransi}

Toleransi diartikan dengan bersikap atau bersifat toleran. Toleran artinya bersifat atau bersikap menenggang (menghargai, membiarkan, membolehkan) pendirian (pendapat, pandangan, kepercayaan, kebiasaan, kelakuan, dsb.) yang berbeda atau bertentangan dengan pendirian sendiri. Karakter toleransi pada novel Surga yang tak Dirindukan karya Asma Nadia dapat diketahui dari kutipan berikut ini.

\section{Kutipan 1}

"Bukan hanya omongan orang. Kamu masih berprasangka baik seperti biasa, Rin. Dunia kita bukan dongeng." (Surga yang tak Dirindukan, 2014: 90).

Kutipan 1 menggambarkan bahwa Arini orang yang selalu berprasangka baik. Arini tidak pernah menghakimi orang lain secara sepihak. Arini juga menghargai orang lain dan ia tidak sombong sehingga ia selalu berprasangka baik kepada orang lain. Berprasangka baik kepada setiap orang ini membuktikan Arini memiliki karakter toleransi.

\section{Kutipan 2}

Arini yang aku kenal dengan cerita-cerita Pras memang bukan seorang pemarah. (Surga yang tak Dirindukan, 2014: 276).

Kutipan 2 menceritakan Arini bukan seorang pemarah. Arini mampu bersikap toleransi kepada orang lain sehingga ia tidak mudah marah kepada orang lain. Orang yang tidak memiliki karakter toleransi akan mudah marah, sedangkan Arini tidak mudah marah. Arini bukan seorang pemarah sehingga Arini memiliki nilai karakter toleransi.

\section{Kutipan 3}

Arini berusaha sekuat tenaga meredam gelegak di hatinya. Dia sangat terluka. Tapi dia bukan perempuan yang terbiasa mengekspresikan kemarahannya. Apalagi mengumbarnya dengan cara tidak terpelajar. (Surga yang tak Dirindukan, 2014: 279).

Kutipan 3 menceritakan perasaan marah Arini saat ia menemui istri kedua suaminya. Arini marah terhadap perempuan yang telah merebut suaminya tersebut. Namun Arini tidak meluapkan kemarahannya. Arini menahan kemarahannya agar ia tidak meluapkannya dengan cara yang tidak terpelajar. Hal tersebut membuktikan bahwa Arini masih memiliki nilai karakter toleransi meski dengan musuhnya sendiri.

\section{e. Tanggung Jawab}

Setiap orang memiliki tanggung jawab terhadap perannya masing-masing. Tokoh Utama tersebut harus melakukan tanggung jawabnya dengan baik. Berikut ini kutipan novel Surga yang tak Dirindukan karya Asma Nadia yang memuat nilai karakter tanggung jawab.

Semula Arini ingin melabrak Pras. Mencaci maki, memukul dan menendangnya kalau perlu. Tapi dia seorang istri. Dan sejak kecil Arini melihat betapa hormat ibu kepada bapak. Ibu tidak pernah merengut, marah apalagi berkata kasar. (Surga yang tak Dirindukan, 2014: 107).

Kutipan di atas menceritakan keingin Arini yang ingin melabrak Pras karena Pras memiliki istri lagi. Namun keinginan itu ia urungkan karena mengingat tanggung jawab seorang istri. Tanggung jawab seorang istri adalah merawat suaminya dan menghormai suaminya. Arini mempelajari itu dari ibunya yang tidak pernah merengut, marah, apalagi berkata kasar pada bapaknya. Tindakan Arini yang menjaga tanggung jawabnya itu membuktikan Arini memiliki karakter tanggung jawab.

\section{f. Kerja Keras}

Kerja keras dapat diartikan suatu usaha yang dilakukan dengan pantang menyerah untuk meraih mimpinya. Kerja keras juga dapat diwujudkan dengan berusaha sunggung-sungguh dan tak hentihenti. Karakter kerja keras pada tokoh Arini di novel Surga yang tak Dirindukan karya Asma Nadia dapat diketahui melalui kutipan berikut.

Arini bangkit dari keterpurukan. Perempuan itu mulai mengetik lagi, jemarinya bermain cepat di atas keyboard. Meski kisah-kisah yang tulisnya tak lagi berakhir bahagia. (Surga yang tak Dirindukan, 2014: 115).

Kutipan di atas menceritakan Arini yang bangkit dari keterpurukannya karena merasa sedih dan kecewa dengan perilku Pras. Namun Arini masih bisa bangkit dari keterpurukan itu. Ia tetap berkarya dengan melanjutkan pengetikan novel yang ia buat. Meski kisah-kisah yang Arini tulis tidak berakhir bahagia, ia tetap melanjutkan karyanya itu. Hal tersebut membuktikan bahwa Arini memiliki nilai karakter kerja keras.

Dari penjelasan di atas, penulis dapat menyimpulkan bahwa dalam novel Surga yang tak Dirindukan karya Asma Nadia terdapat beberapa nilai karakter yang relevan dengan pembelajaran. Nilai karakter tersebut meliputi religius, peduli lingkungan, kreatif, peduli sosial, cinta damai, 
toleransi, tanggung jawab dan kerja keras. Selain itu, penulis juga menyimpulkan bahwa nilai karakter yang paling dominan dalam novel Surga yang tak Dirindukan karya Asma Nadia adalah nilai religius.

\section{SIMPULAN DAN SARAN}

Karakter Tokoh Utama yang terdapat dalam novel Surga Yang Tak Dirindukan, berdasarkan hasil analisis terdiri dari enam karakter tokoh utama. Adapaun karakter tokoh utamadalam novel Surga Yang Tak Dirindukan, yaitu: (a) Religius. Karakter religius diwujudkan dengan taat beribadah, selalu bersyukur kepada Allah, menjalankan semua perintah Allah dan menjauhi semua larangan Allah. (b) Peduli Lingkungan. Peduli lingkungan dapat diwujudkan dengan menjaga kelestarian dan kebersihan lingkungan di sekitar kita. (c)Kreatif. Orang yang kreatif akan melahirkan karya-karya yang berguna bagi orang lain. Karakter ini sangat dibutuhkan untuk mewujudkan peserta didik yang produktif. (d) Toleransi. Toleran artinya bersifat atau bersikap menenggang (menghargai, membiarkan, membolehkan) pendirian (pendapat, pandangan, kepercayaan, kebiasaan, kelakuan, dsb.) yang berbeda atau bertentangan dengan pendirian sendiri. (e) Tanggung Jawab. Tokoh Utama tersebut harus melakukan tanggung jawabnya dengan baik. (f) Kerja Keras. Kerja keras juga dapat diwujudkan dengan berusaha sunggungsungguh dan tak henti-henti.

\section{UCAPAN TERIMA KASIH}

Ucapan terima kasih penulis tujukan kepada siswa-siswi kelas XI SMK Nusantara yang kooperatif dalam melaksanakan penelitian ini. Selain itu, terima kasi penulia haturkan kepada bapak kepala sekolah dan segenap dewan pimpinan serta guru yang memberikan dukungan dalam mewujudkan penelitian ini.

\section{DAFTAR RUJUKAN}

Aminuddin. 2009. Pengantar Apresiasi Karya Sastra. Bandung: Sinar Baru Argesindo.

Endaswara, Suwardi. 2003. Metodologi Penelitian Sastra. Yogyakarta: Pustaka Widyatama.

Nurgiyantoro, Burhan. 2005. Teori Pengkajian Fiksi. Yogyakarta: Gajah Mada University Press.

Pradopo, Rachmad Djoko. 2005. Beberapa Teori Sastra, Metode, Kritik, dan Penerapannya. Yogyakarta: Pustaka Pelajar.

Sujarwanto; Jabrohim, 2001. Bahasa dan Sastra Indonesia Menuju Peran Tranformasi Sosial

Sugiarti, 2011a. "Membangun Karakter Peserta Didik melalui Pembelajaran Sastra". Makalah International Seminar and the 3 rd Colloqium 18-19 Mei 2011. FKIP Universitas Muhammadiyah Malang.

Sugiarti, 2011b. "Kontribusi Sastra dalam Pembentukan Karakter Bangsa”. Didaktik.Majalah Mahasiswa FKIP UMM.

Sugiarti, 2012. "Membangun Karakter Peserta Didik Melalui Pembelajaran Sastra". Makalah Seminar Intenasional Bahasa, Sastra dan Budaya Nusantara. Universitas Muhammadiyah Jakarta 16 Februari 2012.

Suyitno. 1986. Sastra Tata Nilai dan Eksegesis. Yogyakarta: PT Hanindita. 